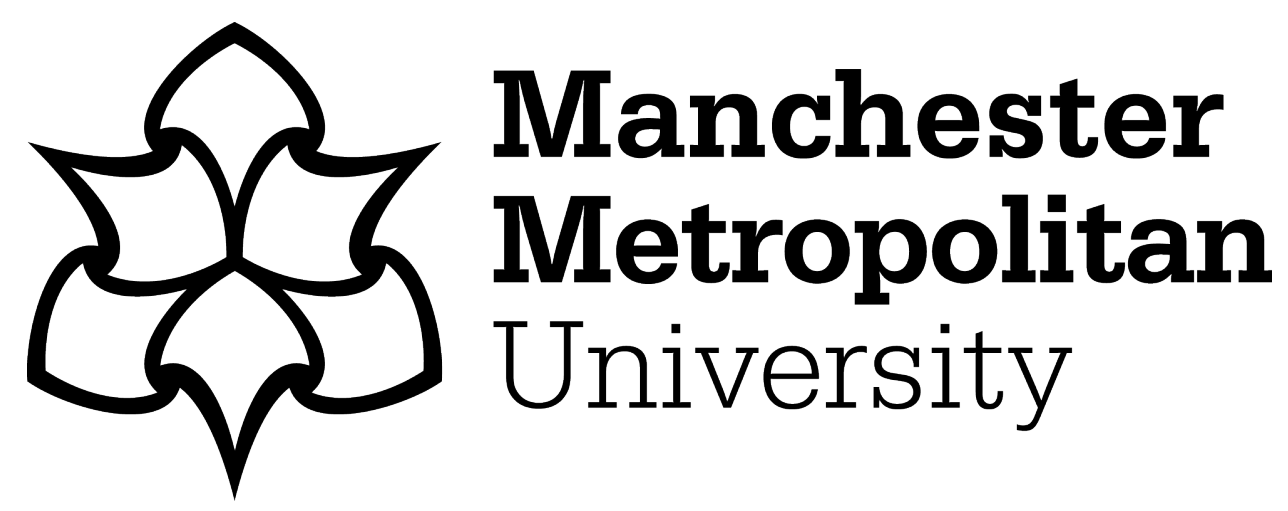

Jimenez Vivas, A and Menendez Alvarez-Hevia, D (2017) Paths, patterns and factors that influence the entry of university graduates into the labour market. European Journal of Higher Education, 7 (4). pp. 388-401. ISSN 2156-8235

Downloaded from: https://e-space.mmu.ac.uk/619187/

Version: Accepted Version

Publisher: Taylor \& Francis

DOI: https://doi.org/10.1080/21568235.2017.1370383

Please cite the published version 


\section{Paths, patterns and factors that influence the entry of university graduates into the labour market}

Dr Amparo Jimenez Vivas

Department of Education, Universidad Pontificia de Salamanca, Salamanca, Spain.

Professor of Professional and Educational Diagnose

*Dr David Menendez Alvarez-Hevia

Department of Childhood, Youth and Education Studies, Manchester Metropolitan

University, Manchester, UK.

Senior lecturer in Education Studies.

*Corresponding author contact details: Brooks Building, 53 Bonsall Street, Manchester, M15 6GX, d.menendez-alvarez-hevia@mmu.ac.uk 


\title{
Paths, patterns and factors that influence the entry of university graduates into the labour market
}

\author{
This article provides an overview of the literature that contributes to the study of \\ the key factors that explain the process by which university graduates enter the \\ labour market. It is approached from the standpoint of the Spanish experience but \\ also discusses other European initiatives. Understanding this process is \\ paramount for the modernisation of the university offering. The entry of \\ university graduates into the labour market is characterised by complex and \\ multiple interrelations of factors that include both contextual/social and \\ individual/personal variables. This study argues that a multidimensional analysis \\ of the process and the different variables involved contributes to the development \\ of appropriate career plans and university employability strategies. The article \\ focuses on discussing the personal variables that shape individual paths and \\ presents an analysis of a number of categories and elements that are essential if \\ the transition from university to the labour market is to take place successfully.
}

Keywords: Labour market entry, professional path, employability, university graduates

\section{Introduction to the socio labour market}

The average rate of unemployment in the EU has never dropped below $6 \%$ but paradoxically in countries like Spain, it has double in the last decade for people who have obtained a degree (Eurostat 2015). Furthermore, in the USA, half of the jobs in which recent university graduates are working do not require a degree (Vedder, Denhart and Robe 2013). According to the OECD, more than 40 million people are unemployed (OECD 2016a). The labour market has been redefined and regulated with the purpose of making it more competitive as part of a globalised world whilst work conditions have also changed because of the implementation of national and international policies.

Different authors criticise the fact that this has been done by prioritising the demands of the market over human, knowledge or worker demands (Holmwood 2014; Brown, Lauder and Ashton 2011) and, as a consequence, it is producing a sense of employment 
vulnerability and instability that is now spreading among industrialised democracies (Rueda 2007). As discussed in Maguire et al. (2013) the current labour market is developing into a "dangerous threat" for young people who perceive how "rigid labour market structures combined with the effects of recession and fiscal restraints on the national budgets of the crisis states make a solidification of youth unemployment likely" (235). Although the probability of higher education graduates of finding a job has been decreasing in many EU countries, the majority of graduates indicate a positive perception on how higher education equip them for work (van der Velden and Allen

2011). To understand the paths, patterns and factors that influence the entry (and success) of university graduates into the labour market has become a priority for educational stakeholders and national and international institutions

\section{The transition to the labour market of university graduates}

The concept of transition to the labour market is understood as being the move from education to working life and it considers different working experiences that lead to full integration in the labour market. Getting a job has become one of the most significant achievements in the transition from adolescence to adulthood. It is through work that individuals become economically independent from parents, get involved in new social relations and have the opportunity to form their own family. Work is thus seen as the main source of income and social status (Garrido and Requena 1997). There is not just one, but various processes that an individual goes through when making the transition from adolescence and education to adulthood and working life (Andrews and Bradley 1997; EGRIS 2001). Although these various processes have different meanings, they are closely interrelated, and the fact that they are connected is an important consideration when it comes to understanding subjectivities in modern times (Hodkinson, Spark and Hodkinson 2012). 
To understand the transition processes comprehensively, it is necessary to consider in detail particular factors that influence how individuals adjust themselves to the flexibility of the labour market. Bisquerra (1998) explains that the transition process is characterised in modern societies by the extension of the period of youth and the formative years, along with the many changes in the existing economic, technological and demographic socio-labour landscape. The transition from youth to a different social category is centred around the idea of getting a specific job, which guarantees economic independence and promotes self-reliance away from parents. The status of being employed provides the individual with a sense of stability, autonomy and, in some cases, self-fulfilment and professional satisfaction.

At the same time, it is important to differentiate between the concepts of professional integration and labour market integration. Whilst the first one is defined by job security and is related to the level and subject area of the particular university qualification, labour market integration is not associated with a long-term contract or a match between qualifications and job demands (Perez 2008). Not all the job experiences relate to the expectations defined by the qualifications obtained at university. However, early experiences are required to facilitate the later progression to professional integration.

To discuss the progression from education to work and the ongoing work trajectory, we refer to a life-long learning process characterised by significant turning points at which vocational and professional choices are made. One of these pivotal moments is the move from university to work, but bearing in mind that this transition process has changed significantly during the last few decades. As Salva and Nicolau (2000) explain, university graduates have moved from a transition that was presented to them as linear, natural and effortless, and that was followed by a permanent and secure 
job for which they were appropriately qualified, to a more intricate and uncertain transition. The process is now longer and more difficult to define. Martinez (2002) notes that the transition from university to working life has experienced continuous and significant delays and it is for this reason that we can observe how career pathways diverge at different moments. The process of professional integration has been influenced by the transformations taking place in the labour market and the lack of effective policies that consider irregular or fragmented trajectories (EGRIS 2001). The high rates of unemployment, temporariness and labour instability are key elements used to define the current financial and economic crisis in which Europe and our globalised world is immersed (Shutt 2010). It has direct implications for those people who are in search of labour market integration, but it is particularly relevant for those who aspire to professional integration because this transition can now be postponed (or has to be) for a long period of time after graduation. As Harvey (2000) states, a degree is no longer "a passport into employment" (7), nor is a career any longer a single job for life.

In this sense and in line with Teichler $(1999,2007,2015)$, this paper argue that, in general, the transition process of university graduates and young people from education to the labour market has changed substantially in the last decade and some of the changes introduced will not fade away. Career paths are now more than ever defined by flexibility and mobility, including change of sector (sectorial change), workplace (geographical change), organisation (employer change) and even employment status (status change), in which the ideas of self-employment and entrepreneurship are expressly encouraged. Flexibility and mobility are, therefore, at the centre of the European employability agenda for graduates (Teichler 2007) but also school leavers (Brzink-Fay 2007). They do not apply exclusively to labour market integration, but to the full extent of working life, including professional integration. This phenomenon is 
characteristic of modern societies, guiding the integration of university graduates into the labour market and the way they then approach professional integration. In the light of this, we can describe the way in which the transition from education to work is effected in the current climate as non-linear or divergent, rather than as sequential or linear; the transition these days does not always take place continually in the same direction. According to Casal (1999), two of the things that this implies are that people stay in education for longer periods and that work experience features more strongly in the curriculum. Moreover, this author also considers some of the negative implications of this model. People have to face the unfortunate emergence of a secondary work market (consisting of mostly part-time and temporary work where the staff turnover is high and the work low paid) that leads to precarious job security. They find out that career choices are confusing and challenging and that the transition process from education to employment is problematic. University graduates retain high expectations based on their extended qualifications, but they soon realise that the labour market is inconsistent, volatile, and driven in part by short-term and partial goals. The conclusions from a qualitative study carried out by the Spanish National Agency for Quality Evaluation and Accreditation (ANECA 2009) shows that despite the multiple changes introduced to modernise universities, Spanish graduates still perceive a gap between the labour market and higher education and have difficulties to recognise some of the most demanded competencies.

Previously, in the INFAPLAN report, Casal, Masjuan and Coll (1991) foresaw the emergence of certain patterns in the process of entry into the labour market and discussed some of the main characteristics of this process in the Spanish context. For the purposes of this paper, the ideas presented in this report have been summarised and expanded to provide a broader and more current view. First, it is considered the 
extension of the transition process. Young people, either intentionally or unintentionally, spend more time in compulsory and non-compulsory education. Consequently, adulthood is postponed and financial dependency on parents extended. In some cases, staying in formal education for longer implies overqualification. Alfes, Shanz and van Baalen, (2016) confirm that overqualification or overeducation have a negative influence when they are associated with lower levels of job satisfaction. These authors also suggest that "cultivating high quality interpersonal relationships at work is an effective way to reduce perceptions of overqualification, as well as the potential negative ramifications of it" (98). Nevertheless, we should not forget that education has been presented as the fundamental factor that defines a person in society, contributing to personal growth, economic prosperity, social mobility, democratic participation and life-long benefits (Delors et al., 1996; Baum, Ma and Payea, 2013).

Second, some groups experience more problems than others in accessing the labour market. However, struggling to enter the world of work is no longer the exclusive province of young and vulnerable people. In a study carried out by Morrison (2014) that explores how university graduates perceive employability issues, he found out that social class, gender and ethnicity are still perceived as determinant factors, suggesting that difficulty in entering the labour market is not only an educational problem but also structural, as "transferable skills come heavily raced, classed and gendered" (195). Moreover, new forms of marginality and discrimination are emerging, and restricted opportunities for accessing employment have been identified as a central dimension of the problem (Giardielo 2016; Anyadike-Danes and McVicar 2010; Dean 2003). A more radical argument is developed in the work of McLaughling (2002) in which it is argued that structural inequalities always put the same people at risk of 
unemployment. It follows that unemployment is not an educational problem but the result of an inefficient economic system based on an economy of unemployment.

Third, this study looks at the expansion of the market for education and its transformation into a popular commodity. Regardless of the introduction of or increase in fees and other changes, there is a growing demand for higher education. However, authors such as Collini (2012) and Scullion, Molesworth and Nixon (2011) make us aware of how the marketisation of higher education is transforming the university setting. In line with this idea, Sin and Neave (2014) add that there is a risk of instrumentalisation if the employability agenda is situated at the centre of education.

Last, gender inequality is examined. Despite the fact that different gender equality policies have been introduced and implemented at different levels, women are still far from being equal with men when we look at the labour market. A recent report from the International Labour Organisation (2016) shows that, in a global context, the gender gap in the labour market is not changing. To illustrate this point, the report states that the participation of women in the labour market persists at almost $27 \%$ lower than that of men. In countries like Spain, the situation has been exacerbated due to the extended period of economic crisis, to the point where the implications are not only of an economic nature (Le Feuvre and Roseneil 2014).

Cuadrado and Iglesias (2003) suggest that in order to understand the transition process from education to labour market studies must focus on understanding the intense and deep structural changes that are taking place. These changes are visible when we look at the occupational structure and distribution of the labour force. For example, can be argued that there is an increase in the level of education, but also that this is associated with youth overqualification (Chartered Institute of Personnel and Development 2015). Additionally, it is also recognised the fact that although more 
women have entered the labour market, they still have to overcome "additional barriers" (Suarez Ortega 2008) in order to do so, some of which have been identified with educational matters (Susinos, Calvo and García 2014).

\subsection{Employability and its practices}

Looking at the arguments put forward here, this study comes to the idea that, given the complexity of the information used to define and classify the different elements involved in the transition process from education to work, a more exhaustive analysis of personal professional paths is needed. This study recognises that an exploration of particular paths will contribute to the development of more effective university employability and careers education strategies. The process of preparing university students for work and the demands and challenges of the job market is traditionally defined as careers education and covers teaching activities but also careers guidance in various formats (see, e.g., Hoyt 1975; Pereira Gonzalez 1995; Irving and Malik 2005). More recently, this idea has been expanded and conceptualised as employability (see, e.g., Williams et. al. 2016; York 2006; MacQuaid and Lindsay 2005).

Employability is associated with the idea of professional integration whereas employment is linked to a more generic integration into the labour market. The literature indicates that employability is a key debate within higher education that influences policy rationality and students motivation, involving multiple stakeholders (students, lecturers, universities, governments etc.) and exploring the relationship between employment opportunities and education (Artess, Hooley and Mellors-Bourne, 2017). From this perspective we can argue that careers education are complex and

multidimensional processes that require both personal and professional development in order to prepare individuals to meet and understand the social and professional demands 
of a volatile labour market (Tymon 2013; Tomilson 2007; Little 2007). Bridgstock (2009) suggests that if universities are to develop effective graduate employability programmes, together with introducing policies that support the employability agenda, they must take into account other factors that contribute to a successful career in the world we live in today, life-long learning, for example, and career management skills. Therefore, higher education must be prepared to respond to the challenges of a globalised and changing world of work that goes beyond the classic teaching and learning classroom interventions (see: Teichler 1999). From this idea, four major international projects on graduates' transition from education to work emerge: REFLEX $^{1}$ (Flexible Professional in the Knowledge Society), CHEERS ${ }^{2}$ (Careers after Higher Education), HEGESCO ${ }^{3}$ (Higher Education as a Generator of Strategic Competences) and PIAAC ${ }^{4}$ (Programme for the International Assessment of Adult Competencies). These studies present the labour market transition and career development as a long and complex process, identifying key factors that influence the labour market "success" and providing guidance for policy makers, institutions, employers, educators and students. Despite the differences identified between countries and areas of knowledge, some of the common elements that appear as related to labour market success are mastery of the discipline (including theoretical knowledge), development and manifestation of key cognitive skills and competences that prepare for

\footnotetext{
${ }^{1}$ See: http://www.hefce.ac.uk/pubs/rereports/year/2008/flexibleprofessional/

${ }^{2}$ See: http://www.qtafi.de/index.php/cheers-european-graduate-survey

${ }^{3}$ See: http://www.hegesco.org/

${ }^{4}$ See: http://www.oecd.org/skills/piaac/
} 
uncertainty and technological changes, institutional cooperation with employers and relevant work experience.

\section{Individual differences and professional paths}

During the process of professional integration, graduates go through different stages, which can overlap, and experience significant turning points prompting different processes that, in turn, result in specific actions. It is through acknowledging the presence of these turning points and the study of the processes and actions emanating from them, that meaningful employability strategies are developed.

The first process is that of decision-making; this relies on the reflective capacity of each person and will facilitate all of life's undertakings, not just the special ones. It requires personal introspection in conjunction with an understanding of the possibilities of the labour market. As part of this reflective strategy, personal competencies, attitudes, motivations and expectations are analysed and aligned with a realistic perception of labour market opportunities available in a specific context. This initial stage is a fundamental basis for developing career plans whilst at university and is defined as reflexive and informing. It is established from a thorough analysis of interpersonal abilities and capacities, together with an examination of the job and educational opportunities that are available in a given context.

The initial approach to the labour market is also perceived as a key process and is associated with the use of job search skills to seek employment. It involves, among other things, utilising self-promoting techniques to put into action the decision about entry into the labour market that has been made.

First experiences are of considerable benefit in evaluating the initial plan. Those processes that precede entry to the labour market are also interconnected with the process of assimilating the skills and abilities that it demands. It is for this reason that 
some undergraduate programmes want very much to offer their students opportunities to interact and get involved in a specific work culture. As Hayler and Lee (2014) expound, there is a growing interest in providing opportunities "to experience the workplace through real-work projects - work placements, internships and other collaborations with businesses" (349).

Nevertheless, in this article is also argued that each case is different and requires careful attention. It is for this reason that the model proposed by Figuera (1996) is founded useful for discussing individualities. In this model, the diverse paths followed by university graduates are examined by looking at how different profiles are associated with different patterns of integration into the labour market. From this perspective, three profiles of students emerge:

\begin{tabular}{|c|c|c|}
\hline & a) Hard Student Profile & $\begin{array}{l}\text { The undergraduate is represented as a student. } \\
\text { Whilst he or she may have some sporadic contact } \\
\text { with the labour market, this work experience will } \\
\text { be very limited (e.g. work placements, a voluntary } \\
\text { job or work on a casual basis). }\end{array}$ \\
\hline & $\begin{array}{l}\text { b) Mixed Student } \\
\text { Profile or Employee- } \\
\text { student }\end{array}$ & $\begin{array}{l}\text { Combines a balance between study and work and, } \\
\text { in some cases, is acknowledged as the first stage } \\
\text { of a professional career since the work is related } \\
\text { to the subject of study (e.g. part-time worker and } \\
\text { part-time student). }\end{array}$ \\
\hline $\begin{array}{c}\text { Profiles of } \\
\text { Student }\end{array}$ & $\begin{array}{l}\text { c) Pure Professional } \\
\text { profile }\end{array}$ & $\begin{array}{l}\text { Presents a combination of study and work, with } \\
\text { the main activity being work. It involves studying } \\
\text { during free time or distance learning (e.g. online } \\
\text { courses, blended learning, etc.) and the main } \\
\text { objective could be either internal promotion or a } \\
\text { career change: } \\
\text { - If the main aim is internal promotion, } \\
\text { the student would choose a subject } \\
\text { associated with the sector in which } \\
\text { he/she is already working } \\
\text { - If the main aim is a change of career, } \\
\text { he/she would choose a different area of } \\
\text { study. In this case, re-entry into the } \\
\text { labour market will be required. }\end{array}$ \\
\hline
\end{tabular}

Table 1: Profiles of students 
To expand this model further studies suggest that the profiles are not static categories as it is common to see students change their profiles, mainly during the last stages of their studies. Mixed student and pure professional profiles require special attention, as different studies make it clear that employment has an impact on students' experiences, engagement and performance (Hall 2010; Moreau and Leathwood 2006a; Broadbridge and Swanson 2005; Curtis and Shani 2002).

It is also worth mentioning that this categorisation can lead to stereotypical classifications. The construction of these categories also rests on other factors, such as the subject studied, level of study, gender or socio-economic background of the student. However, for the purpose of this study is appreciated that this model presents a valuable framework for articulating discussions about individual profiles.

In order to update previous classifications and find out more about individual experiences, this study revisited the classification advanced by Martinez (2002) who proposes six professional paths as a way to categorise differences with regard to the process of transition from education to work.

\begin{tabular}{|l|l|}
\hline \multirow{4}{*}{ Professional Paths } & 1. Early Success Path \\
\cline { 2 - 2 } & 2. Working Path \\
\cline { 2 - 2 } & 3. Family Path \\
\hline & 4. Trial and Error Approximation Path \\
\cline { 2 - 2 } & 5. Precarious Path \\
\cline { 2 - 2 } & 6. Shapeless, unstructured or blocked Path \\
\hline
\end{tabular}

Table 2. Professional Paths

The first three are the early success path, which is representative of young people with a good academic profile, and who have easy access to a successful and stable career without breaks. It was common in Western societies during the $1980 \mathrm{~s}$ (Moy 1985; McLaughling 2002); the working path, the category for young people who are unqualified or who have vocational qualifications, and which is characterised by career and job variations; and the family path, where the professional career is 
articulated around the family business in which the professional activity will be contextualised. The focus here is not on getting a job but on being able to contribute to the sustainability or expansion of the family business. Lansberg and Gersick (2015) describe three fundamental ways in which education contributes to a family business: first, education raises awareness of the fundamental issues; second, education provides a language with which family owners can frame their reality and problem-solve collectively; third, education provides hope by presenting unrealised possibilities that may be within a given family's reach.

Following on from the first three categories derives the trial and error approximation path, the trajectory of which is characterised by an unstable employment record that includes periods of unemployment, underemployment or training. Young people who fall into this category are continuously adapting their labour market prospects and experience economic instability. One of the consequences is that they struggle to become economically independent. Since the financial crisis of 2007, this phenomenon has been exacerbated and, as Gentile (2013) explains, not only has it had an impact on the personal autonomy of young people, it has affected relations between generations. He goes on to say that it has also made the sustainability of the current Spanish welfare state difficult due to the increasing benefits bill. The difficulty of becoming independent from families is a common point in the final two categories: the precarious path, which is associated with employment uncertainty and negative experiences in the labour market; and the shapeless, unstructured or blockaded path, which is characterised by long periods of unemployment and total dependency.

However, this article would like to suggest that a more detailed analysis must consider studies that show how some groups of students deal with class, age, gender, disability or ethnic based disadvantages and how it affects the paths they follow with 
regard to entry into the labour market (see, e.g., Morrison 2014; Andrew 2009; Moreau and Leathwood 2006b).

The models previously proposed provide a theoretical framework that contributes to systematising and understanding young people's stories about and experiences in the labour market. From this standpoint, this study has indicated how the discussions about the relationship between education and employment have evolved from socio-economic approaches (where different professional paths define entry to the labour market) to personalised approaches (that consider individual skills and capacities) resulting in a comprehensive and multidisciplinary model in which both social and individual aspects are considered. It is not our aim in this paper to conceptualise the different theoretical approaches, but this study wanted to highlight them in order to stress the complexity of the subject under discussion.

\section{Some of the determining factors with regard to professional integration of university graduates}

Following on from the previous discussion, this study proposes to employ a dualistic model in order to explore the factors involved in the process of professional integration. Henceforth, the study of personal or individual factors (embedded in the individual) and social or contextual factors (preset by the labour market). Whilst it is understood that these factors exist in a very complex system, which includes overlaps, interactions and supplementary issues, in focusing on this two-way distinction, arguments that are accessible for all the actors can be articulated (from students to people involved in careers advisory services or university programme design).

When the personal or individual characteristics that directly influence the possibilities of professional integration are examined, the capacity to regulate and manipulate them is limited. Some of the individual characteristics are determined in 
different ways (e.g. gender, age or social context) and so they are not easy to

manipulate. However, there is also space for interventions. This study suggests that this space needs to be utilised by professionals involved in careers advisory services and researchers interested in the field of employability.

Drawing on the model proposed by Garcia-Montalvo, Peiro and Soro (2003), which is used to discuss the process of professional integration, this study proposes a series of factors that can be explored to identify and evaluate areas of intervention. This model is summarised and expanded in the following table to facilitate understanding.

\begin{tabular}{|l|l|l|}
\hline Factor & Focus & $\begin{array}{l}\text { Area of individual } \\
\text { intervention }\end{array}$ \\
\hline $\begin{array}{l}\text { 1. Economic, educational and } \\
\text { work context }\end{array}$ & $\begin{array}{l}\text { Demands of the labour } \\
\text { market }\end{array}$ & $\begin{array}{l}\text { Evaluation of the context } \\
\text { in relation to qualifications } \\
\text { and relevant skills and } \\
\text { competencies }\end{array}$ \\
\hline $\begin{array}{l}\text { 2. Labour market entry and } \\
\text { lived experience }\end{array}$ & $\begin{array}{l}\text { Significant stages of the } \\
\text { professional integration } \\
\text { process together with } \\
\text { subjective experiences }\end{array}$ & $\begin{array}{l}\text { Produce a personalised } \\
\text { picture that also includes } \\
\text { job attitudes, psychological } \\
\text { and behavioural patterns }\end{array}$ \\
\hline $\begin{array}{l}\text { 3. Job seeking, employment, } \\
\text { unemployment and inactivity } \\
\text { the job market and holding } \\
\text { down job difficulties }\end{array}$ & $\begin{array}{l}\text { Review job-seeking skills, } \\
\text { looking at attitudes } \\
\text { towards doing a particular } \\
\text { job and developing career } \\
\text { management skills (see: } \\
\text { (Michelson and Ryan 2014; } \\
\text { Blustein, Cozan and } \\
\text { Connors-Kellgren 2013; } \\
\text { Jones et al. 1982). }\end{array}$ \\
\hline $\begin{array}{l}\text { 4. Job requirement and } \\
\text { personal characteristics } \\
\text { alignment }\end{array}$ & $\begin{array}{l}\text { Overqualification/ } \\
\text { underqualification }\end{array}$ & $\begin{array}{l}\text { Produce a broader picture } \\
\text { of the local context. Bunel } \\
\text { and Tobal (2014) suggest } \\
\text { the use of different models } \\
\text { for measuring local labour } \\
\text { market accessibility }\end{array}$ \\
\hline $\begin{array}{l}\text { 5. Labour flexibility associated } \\
\text { economy }\end{array}$ & $\begin{array}{l}\text { Instability and uncertainty of } \\
\text { local jobs in a specific } \\
\text { geographical context }\end{array}$ & $\begin{array}{l}\text { Recognise that is necessary } \\
\text { to be prepared for a } \\
\text { flexible approach toward } \\
\text { employment (Teichler } \\
\text { 2007) }\end{array}$ \\
\hline $\begin{array}{l}\text { Discuss mismatch with } \\
\text { potential employers } \\
\text { bearing in mind that the } \\
\text { phenomenon of } \\
\text { overqualification is }\end{array}$ \\
\hline
\end{tabular}




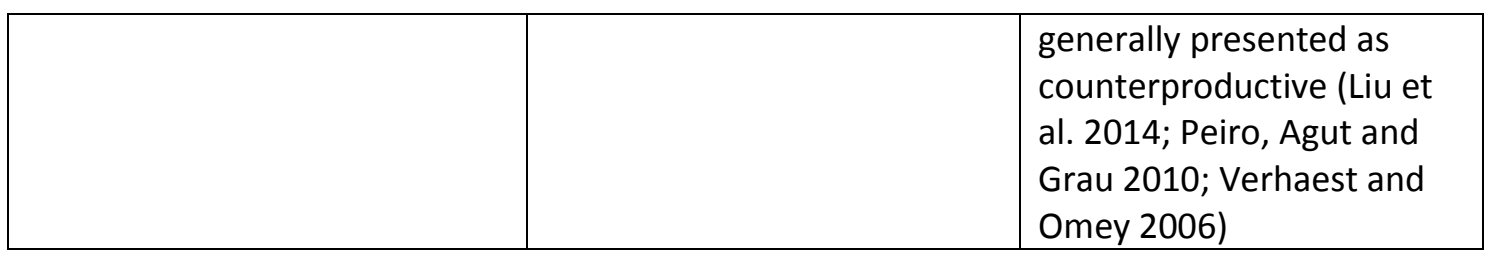

Table 3. Factors, focus and areas of intervention for professional integration.

The interaction of the different elements or variables involved in the professional integration process of university graduates is a complex and multidimensional phenomenon. Its study must be based on the notion that this process is dynamic, individual and changes over time and according to socio-economic context. Moreover, a multidisciplinary approach must be prioritised since it brings different areas of knowledge into discussion (e.g. education, economy, psychology, etc.). Bearing in mind that Rodriguez and Prades (2003) emphasise the singularities of each discipline, this study is contributing to understanding the process of professional integration by introducing an epistemological turn.

It is important to point out that the relationship between education and employment is influenced by multiple factors and, thus, single variable or direct explanations must be problematised. For this reason, the aim of this paper is not to present a single narrative that explains the full process of professional integration, but to present different arguments that facilitate discussions about employability. Gaio Alves (2005) explains that whilst traditional models present professional integration as a response of the educational system to meeting economic and professional demands, a multidimensional model is necessary to understand the complexity of the phenomenon. From a multidimensional perspective, the professional integration of university graduates is associated with market demands (specific to the area of study), personal and social characteristics, educational variables and individual expectations. This shift is described by Trottier (2002) as a transition from a point at which traditional models 
dominated the discussion, to a point at which new theoretical models, which include multiple interpretations and perspectives, are welcomed.

\section{Conclusion}

The arguments presented here could be expanded by an examination of skills, competencies and psychological approaches that would be required at different stages of a career. This could be done by considering skills, abilities and competencies that are associated with the life-long learning process but also reflecting on the limits and possibilities of educational actions. Employability is not only associated with the development of competencies, attributes and abilities that the labour market now demands, but also with abilities and skills that improve an individual's chances of getting and keeping a job (Garcia Manjon and Perez Lopez 2008; Yorke 2006).

It is not the intention of this paper to present a discussion about competencies, but an analysis of other important elements that help us to understand the transition from education to the labour market. The labour market integration of university graduates is a complex process that involves analysing, interrogating and combining the different elements or variables (Donoso and Figuera 2007). External and structural factors should not be ignored since they influence educational interventions and employability success. It is not the solely responsibility of specific educational stakeholders or educational institutions (e.g. students-graduates, lecturers or universities) but a common responsibility in which educational and non-educational elements are entangled This study identified ways of articulating the discussion by considering personal and social elements together with recent socio-economic changes that influence the labour market landscape. In this article has been argued that the interaction of all these elements produces career paths that are characterised by diversity and discontinuity. 
Finally, this study considers that it is necessary to implement plans within the educational system that support young people in their transition from education to the labour market. To contribute to the modernisation of higher education, education itself, vocational training and employment must be connected. It is vital that contributions from educational researchers interested in this area focus on identifying and understanding the relationship between the different elements since it will be useful for the development of effective personal action plans, employability strategies and pedagogies for employability. It is necessary to plan educational strategies that consider the transition process from education to the labour market. This idea is already present in the common higher education spaces of Europe and Latin America as a response to recent social, educational and labour market challenges (Garcia Manjon and Perez Lopez 2008) and countries like Australia have also been discussing interventions to facilitate labour market integration for university graduates (see, e.g., OECD 2016b).

\section{Reference List}

Alfes,K., Shanz, A. and van Baalen, S. 2016. "Reducing perceptions of overqualification and its impact on job satisfaction: the dual roles of interpersonal relationships at work.” Human Resource Management Journal, 26 (1): 84- 101. doi: doi: 10.1111/1748-8583.12094

Allen, J., Ramaekers, G. and Van Der Velden, R. 2003. "La medición de las competencias de los titulados superiores" in Métodos de análisis de la inserción laboral de los universitarios, edited by J. Vidal, 31-54 . Salamanca: Consejo de Coordinación Universitaria, Ministerio de Educación, Cultura y Deporte de la Universidad de León.

ANECA (2009) Los procesos de inserción laboral de los titulados universitarios en España. Accessed 14 August 2017. http://www.aneca.es/Documentos-ypublicaciones/Estudios-de-interes-para-el-ambito-universitario/Los-procesos-deinsercion-laboral-de-los-titulados-universitarios-en-Espana

Andrew, A. 2009. "Challenging Boundaries to 'Employability': Women Apprentices in a Non-Traditional Occupation.” Social Policy and Society 8 (3): 347-359. doi:10.1017/S1474746409004898

ANECA 2004. Encuesta de inserción laboral. Madrid: Omán. 
Anyadike-Danes, M. and McVicar, D. 2010. "My Brilliant Career: Charasterizing the Early Labor Market Trajectories of British Women from Generation X”. Sociological Methods \& Research, 38 (3): 482-512. doi: 10.1177/0049124110362968

Artess, J., Hooley, T. and Mellors-Bourne, R. 2017. Employability: A Review of the Literature 2012-2016. York: Higher Education Academy

Baum, S., Ma, J. and Payea, K. 2013. Education Pays 2013: The Benefits of Higher Education for Individuals and Society. New York: The Colleague Board.

Bisquerra, R. 1998. Modelos de orientación e intervención psicopedagógica. Madrid: Praxis.

Beneitone, P., Esquetini, C., Gonzalez, J., Maleta, M., Siufi, G. and Wagenaar, R. 2007. Tuning América Latin: Reflexiones y perspectivas de la educación superior en América Latina. Bilbao: Servicio de publicaciones de la universidad de Deusto.

Blustein, D., Kozan, S. and Connors-Kellgren, A. 2013. "Unemployment and underemployment: A narrative analysis about loss." Journal of Vocational Behavior 82: 256-265. http://dx.doi.org/10.1016/j.jvb.2013.02.005

Bridgstock, R. 2009. “The graduate attributes we've overlooked: enhancing graduate employability through career management skills." Higher Education Research \& Development 28 (1): 31-44. doi: 10.1080/07294360802444347

Broadbridge, A. and Swanson, V. 2005. Earning and learning: how term-time employment impacts on students' adjustment to university life. Journal of Education and Work 18 (2): 235-249. doi:10.1348/000709905X65009

Brown, P., Lauder, H., and Ashton, D. 2011 The global auction: The broken promises of education, jobs and incomes. New York: Oxford University Press.

Brzinsky-Fay, C. 2007. "Lost in Transition? Labour Market Entry Sequences of School Leavers in Europe”. Eurpean Sociology Review, 23(4): 409-422. doi:

https://doi.org/10.1093/esr/jcm011

Bunel, M. and Tovar,E. 2014. "Key Issues in Local Job Accessibility Measurement: Different Models Mean Different Results." Urban Studies, 51(6): 1322-1338. doi: $10.1177 / 0042098013495573$

Casal, J. 1999. "Modalidades de transición profesional y precarización del empleo". In Juventudes, mercados de trabajo y políticas de empleo, edited by L. Cachón, 151-180. Valencia: Benicull de Xúquer,

Casal, J., Masjuan, J.M. and Coll, C. 1991. La inserción social y profesional de los jóvenes. Madrid: CIDE.

Chartered Institute of Personnel and Development (2015) Over-qualification and skills mismatch in the graduate labour market. accessed 10 July 2016. 
https://www.cipd.co.uk/binaries/over-qualification-and-skills-mismatch-graduatelabour-market.pdf.

Collini, S. 2012. What are universities for? London: Penguin Books.

Cuadrado, J.R. and Iglesias, C. (2003) Cambio sectorial y desempleo en España.

Bilbao: Fundación BBVA.

Curtis, S. and Shani, N. 2002. "The Effect of Taking Paid Employment During Termtime on Students' Academic Studies". Journal of Further and Higher Education 26 (2): 129-138. doi: 10.1080/03098770220129406

Dean, H. 2003. Re-conceptualising Welfare-to-Work for People with Multiple Problems and Needs. Journal of Social Policy 32 (3): 441-459. doi:

$10.1017 / \mathrm{S} 0047279403007062$

Delors, J. et al. 1996. Learning: The Treasure Within. Paris: UNESCO.

Donoso, T. and Figuera, M. P. 2007. Niveles de diagnóstico en los procesos de inserción y orientación profesional. Revista Electrónica de Investigación Psicoeducativa 11, 5 (1):103-124.

European Network of Youth Researchers. 2001. "Misleading Trajectories: Transition Dilemmas of Young Adults in Europe. Journal of Youth Studies 4 (1): 101-118. doi: $10.1080 / 13676260120028574$

Eurostat 2015. "Employment and Unemployment (labour Force Survey)". Accessed 11 August 2016. http://ec.europa.eu/eurostat/web/lfs/data/main-tables,

Figuera, P. 1996. La inserción del universitario en el mercado de trabajo. Barcelona: EUB.

Gaio Alves, M. 2005. La inserción profesional de titulados superiores desde una perspectiva educativa. Revista Europea de formación profesional CEDEFOP 34: 30-33.

Garcia Manjon, J.V. and Perez Lopez, C. 2008. "Espacio Europeo de Educación Superior, competencias profesionales y empleabilidad". Revista iberoamericana de Educación 46 (9): 1-12.

Garcia-Montalvo, J., Peiro, J.M. and Sora, A. 2003. Observatorio de la inserción laboral de los jóvenes 1996-2000. Madrid: Capital Humano.

Garrido, L. and Requena, M. 1997. La emancipación de los jóvenes en España. Madrid: Ministerio de Trabajo y Asuntos Sociales.

Gentile, A. 2003. Emancipación juvenil en tiempos de crisis: Un diagnóstico para impulsar la inserción laboral y la transición residencial. Madrid: Fundacion Alternativas. 
Giardiello, M. 2016. Marginality and Modernity. New Brunswick: Transaction Publisher.

Gonzalez, J. and Wagenaar, R. 2006. Tuning educational structures in Europe II. Bilbao: Universidad de Deusto.

Harvey, L. 2000. "New realities: The relationship between higher education and employment." Tertiary Education and Management 6(1): 3-17. doi:

10.1023/A:1009685205201

Heyler, R. and Lee, D. 2014. "The role of work experience in the future employability of Higher Education graduates." Higher education quarterly 68 (3): 348-372. doi: 10.1111/hequ.12055

Hall, R. 2010. "The work-study relationship: experiences of full-time university students undertaking part-time employment." Journal of Education and Work 23 (5): 439-449. doi:10.1080/13639080.2010.515969

Holmwood, J. 2014. "From social rights to the market: neoliberalism and the knowledge economy." International Journal of Life Long Education 33 (1): 62-76. doi: $10.1080 / 02601370.2013 .873213$

Hoyt, K. B. 1975. An Introduction To Career Education. Washington: U.S. Department of Health, Education, and Welfare.

Hodkinson, P., Spark. A. C. and Hodkinson, H. (2012) Triumps and tears: Young People, Market and the Transition from School to Work. Oxon: Routledge

International Labour Organisation (2016) Woment at Work. accessed 8 September 2016.http://www.ilo.org/wcmsp5/groups/public/---dgreports/---dcomm/--publ/documents/publication/wcms 457086.pdf

Irving, B. A. and Malik, B. 2005 Critical reflections on career education and guidance: Promoting social justice in a global economy. London: Routledge Falmer.

Jones, A., Main, D.S., Butler, M.C and Johnson, L. 1982. "Narrative job descriptions as potential source of job analysis rating." Personnel Psychology 35: 813-828. doi: 10.1111/j.1744-6570.1982.tb02224.x

Lansberg and Gersick. 2015. "Educating Family Business Owners: The Fundamental Intervention". Academy of Management Learning \& Education 14 (3): 400-413. doi: 10.5465/amle.2014.0254

Le Feuvre, N. and Roseneil, S. 2014. "Entanglements of Economic and Intimate Citizenship: Individualization and Gender (In) Equality in a Changing Europe". Social Politics, 21(4): 529-56. doi: https://doi.org/10.1093/sp/jxu010

Little, B. 2003. International perspectives on Employability, Briefing Paper. York: The Higher Education Academy. 
Liu, S., Luksyte, A., Zhou, L., Shi, J. and Wang, M. 2014. Overqualification and counterproductive work behaviors: Examining a moderated mediation model. Journal of Organizational Behavior 36 (2): 250-271. doi: 10.1002/job.1979

Maguire, S. et al. 2013. Youth unemployment, Intereconomics 48 (4): 196-235.

Martinez, R. 2002. La inserción laboral de los universitarios: evaluación de las prácticas en empresas en la Universidad de Granada. Granada: Universidad de Granada.

Martyn, A. and Bradley, S. 1997. "Modelling the transition from school and the demand for training in the United Kingdom.” Economica 64 (255): 387-413. doi: 10.1111/14680335.00087

McLaughling, J. 2002. Understanding Unemployment. London: Routledge.

Michelson, G. and Ryan, S. 2014. Just Work: Narratives of Employment in the 21st Century. London: Palgrave Macmillan.

Moreau, M-P and Leathwood, C. 2006a. "Balancing paid work and studies: working (class) students in higher education." Studies in Higher Education 31(1), pp. 23-42.doi: 10.1080/03075070500340135

Moreau, M.-P. and Leathwood, C. 2006b. "Graduates employment and the discourse of employability: a critical analysis." Journal of Education and Work 19 (4): 305-24. doi: $10.1080 / 13639080600867083$

Morrison, A. 2014. You have to be well spoken: students views on employability within the graduate labour market. Journal of education and work 27 (2): 179-198. doi: $10.1080 / 13639080.2012 .742178$

Moy, J. 1985. "Recent trends in unemployment and the labor force, 10 countries."Monthly Labor Review, 108 (8): 9-22.

McQuaid, R. and Lindsay, C. 2005. "The concept of Employability." Urban Studies, 42 (2): 197-219. doi: 10.1080/0042098042000316100

Organisation for Economic Cooperation and Development (OECD) 2016a. OECD Employment Outlook 2016. Paris: OECD Publishing.

Organisation for Economic Cooperation and Development (OECD) 2016b. Investing in Youth: Australia, investing in youth. Paris: OECD Publishing.

Pereira Gonzalez, M. 1995. La Fundamentacion Teorica de la preparacion para la careera. Revista de Educacion 307: 309-338.

Peiro, J. M., Agut, S., and Grau, R. 2010. "The relationship between overeducation and job satisfaction among young Spanish workers: The role of salary, contract of 
employment, and work experience." Journal of Applied Social Psychology 40: 666-68. doi: $10.1111 / \mathrm{j} .1559-1816.2010 .00592 . x$

Perez Muñoz, S. 2008. "Inserción al mercado laboral: Conceptos relacionados y modelos de transición”. Papeles Salmantinos de Educación 10: 139-161.

Rodriguez, S. and Prades, A. 2003 La evaluación de la transición al mercado laboral de las universidades catalanas. In Métodos de análisis de la inserción laboral de los universitarios, edited by J. Vidal, 95-105. Salamanca: Consejo de Coordinación Universitaria- Ministerio de Educación, Cultura y Deporte.

Rueda, D. 2007. Social Democracy Inside Out: Partisanship and Global Market Policy in Industrialized Democracies. Oxford: Oxford University Press.

Saavedra, M. G. 2008. Postgrados y demandas laborales: la evaluación de las profesiones. Revista Iberoamericana de Educación 46 (9): 1-14.

Salva, F. and Nicolau, I. 2000. Formación e inserción laboral. Conceptos básicos, políticas, programas y recursos para la intervención. Madrid: Pirámide.

Scullion, R., Molesworth, M. and Nixon, E. 2011. The marketisation of higher education and the student as consumer. Abingdon: Oxon: Routledge.

Shutt, H. 2010. "The global unemployment pandemic and its consequences for income distribution." World Review of Political Economy 1 (2): 264-274.

Sin, C. and Neave, G. (2014) Employability deconstructed: perceptions of Bologna stakeholders, Studies in Higher Education 41 (8): 1447-1462. doi:

$10.1080 / 03075079.2014 .977859$

Suarez Ortega, M. 2008. El proyecto profesional y de vida de mujeres con escasa cualificación. Sevilla: Consejo Andaluz de Relaciones Laborales.

Susinos, T., Calvo, A. and García, M. 2014. "Retrieving feminine experience: Women's education in twentieth-century Spain based on three school life histories". Women's Studies International Forum 31(6): 424-433. doi: 10.1016/j.wsif.2008.09.004

Teichler, U. 2015. "Changing Perspectives: the Professional Relevance of Higher Education on the Way Towards the Highly-Educated Society". European Journal of Education 50 (4): 461 - 477.

Teichler, U. 2007. "Does Higher Education Matter? Lessons from a Comparative Graduate Survey" European Journal of Education 42 (1): 11-34

Teichler, U. 1999. "Higher education policy and the world of work: changing conditions and challenges. Higher Education Policy 12: 285-312. 
Tomilson, M. 2007 "Graduate employability and student attitudes and orientations to the labour market." Journal of education and work 20 (4): 285-304. doi:

$10.1080 / 13639080701650164$

Trottier, C. 2002. "La sociologie de 1'educacion et l'insertion professionelle des jeunes." Education et sociétés 7 (1): 5-22. doi: 10.3917/es.007.0005.

Tymon, A. 2013. "The student perspective on employability." Studies in Higher Education 38 (6): 841-856. doi: 10.1080/03075079.2011.604408

van der Velden, R. and Allen, J. 2011. The Flexible Professional in the Knowledge Society: Required Competences and the Role of Higher Education in The Flexible Professional. In The Flexible Professional in the Knowledge Society, edited by Allen and Van der Velden, 15-53. Maastricht; Springer

Vedder, R., Denhart, C. and Robe, J. 2013. "Why Are Recent College Graduates Underemployed? University Enrollments and Labor-Market Realities. ” Washington: Center for College Affordability and Productivity.

Verhaest, D. and Omey, E. 2006. "The Impact of Overeducation and Its Measurement." Social Indicators Research, 77 (3): 419-448. doi: 10.1007/s11205-005-4276-6

Williams,S., Dodd, L., Steele, C. and Randall, R. 2016. "A systematic review of current understandings of employability." Journal of Education and Work, 29 (8), pp. 877901.doi: 10.1080/13639080.2015.1102210.

Yorke, M. 2006. Employability in Higher Education: What It Is - What It Is Not. York: Higher Education Academy. 